\title{
A new model for computing the evolution of the extracellular, innercellular and membrane potential simultaneously
}

\author{
Konstantinos Xylouris*, Gabriel Wittum \\ From Nineteenth Annual Computational Neuroscience Meeting: CNS*2010 \\ San Antonio, TX, USA. 24-30 July 2010
}

In order to model extracellular potentials the LineSource method provides [1] a very powerful and accurate approach. In this method transmembane fluxes are understood as sources for potential distributions which obey the Poission-equation with zero boundary conditions in the infinity. Its solutions reveal that the waveforms are proportional to local transmembrane net currents. The extracellular potentials are comparable small in amplitude and with the aid of their second special derivatives, it is possible to interpret them as additional fluxes to be included into the cable equation having an impact on the membrane potential of surrounding cells [2]. On this basis ephaptic interactions have been studied and have been considered to play a minor role in the network activity.

This modeling study provides a new approach based on the first principle of the conservation of charges which leads to a generalized form of the cable equation taking into account the full three-dimensional detail of the cell's geometry and the presence of the extracellular potential. So instead of coupling the compartment model and the model for extracellular potentials by means of the transmembrane currents, a non-linear system of partial differential equations is solved. Because the abstraction of deviding the cell's geometry into compartments falls apart, it is possible to examine the contribution of the precise cell geometry to the signal processing while not neglecting the impact which could result from the extracellular potential.

Some simulations of propagating action potentials on ramified geometries are going to be shown as well as the resulting distributions of extracellular action potentials.

\footnotetext{
* Correspondence: konstantinos.xylouris@gcsc.uni-frankfurt.de
} G-CSC, University of Frankfurt State
Published: 20 July 2010

\section{References}

1. Gold C, Henze Koch C, György B: On the Origin of the Extracellular Action Potential Waveform: A Modeling Study. J. Neurophysiol 2006, 95:3113-3128.

2. Holt GR, Koch C: Electrical Interactions via the Extracellular Potential Near Cell Bodies. J. Comput. Neurosci. 1999, 6:169-184.

doi:10.1186/1471-2202-11-S1-P139

Cite this article as: Xylouris and Wittum: A new model for computing the evolution of the extracellular, innercellular and membrane potential simultaneously. BMC Neuroscience 2010 11(Suppl 1):P139.
Submit your next manuscript to BioMed Central and take full advantage of:

- Convenient online submission

- Thorough peer review

- No space constraints or color figure charges

- Immediate publication on acceptance

- Inclusion in PubMed, CAS, Scopus and Google Scholar

- Research which is freely available for redistribution

Submit your manuscript at www.biomedcentral.com/submit
C Biomed Central 